\title{
RECENT INCIDENCE OF TYPE 1 DIABETES MELLITUS IN MONTENEGRO: A SHIFT TOWARD YOUNGER AGE AT DISEASE ONSET
}

\author{
Mira Samardžić ${ }^{1}$, Milica Martinović ${ }^{2}$ Mirjana Nedović-Vukovićc ${ }^{3}$ and Milena Popović-Samardžić ${ }^{3}$ \\ ${ }^{1}$ Institute for Sick Children; ${ }^{2}$ Medical Faculty of Montenegro; ${ }^{3}$ Institute of Public Health of Montenegro, \\ Podgorica, Montenegro
}

\begin{abstract}
SUMMARY - In the last several decades, a great number of studies have pointed to a dramatic increase of type 1 diabetes mellitus (T1DM) incidence in the whole world, especially in younger age groups. Therefore, the aim of the study was to assess changes in the age distribution at onset of T1DM in Montenegro children aged <15 years during a 15-year period (1997-2011) and analyze the seasonal pattern. Primary case ascertainment was from diabetes register, secondary and tertiary independent data sources were hospital case records and register of children receiving free test stripes in pharmacy. Standardized incidence rates were calculated using the Poisson regression. Case ascertainment was $100 \%$ complete using the capture-recapture method. The mean age-standardized incidence was 18.6/100,000 (95\% CI: 13.0-24.1) from 2007 to 2011 compared with 13.4/100,000 95\% CI, 11.5-15.5) from 1997 to 2006. The incidence of T1DM increased predominantly in younger age groups. Relative increase of incidence per 5 -year period was largest in boys aged 0-4 and 5-9 years: 64.7\% (95\% CI: 20.6-10.7; p=0.004) and 52.8\% (95\% CI: 16.9-88.8; $\mathrm{p}=0.004)$, respectively. Seasonality in monthly case counts of T1DM was apparent. The greatest number of cases were diagnosed during autumn and winter months. In conclusion, the onset of T1DM was found to occur at an ever younger age in Montenegro children. Our results indicated a seasonal pattern of the disease onset.
\end{abstract}

Key words: Diabetes mellitus, type 1; Child; Incidence; Epidemiology; Montenegro

\section{Introduction}

Two international childhood-onset type 1 diabetes registries (EURODIAB and DIAMOND) deal with research of the epidemiology of diabetes, which is necessary for understanding the etiopathogenesis of type 1 diabetes (T1DM). Application of standardized methods showed great variations in diabetes incidence rates, dramatic increase in the incidence of T1DM in the whole world, earlier clinical presentation of the disease, and seasonal variation ${ }^{1}$. According

Correspondence to: Prof. Mira Samardžić, $M D, P h D$, Institute for Sick Children, Department of Endocrinology and Diabetes, Ljubljanska bb, 81000 Podgorica, Montenegro

E-mail: samardzic@t-com.me

Received August 13, 2015, accepted December 7, 2015 to EURODIAB, in Europe the highest rates of childhood diabetes are found in Scandinavia and northwest Europe, with an incidence ranging from 57.4 cases 100,000 per year in Finland to the lowest rate of 3.9/100,000 in FYR Macedonia. The annual growth of incidence is $3.9 \%$ (1989-2003) and it is noticeable in all age groups, mostly in children aged $0-4$ years $(5.4 \%)^{2,3}$.

During the last twenty years, greatest changes in the incidence of T1DM occurred in the countries of Central and Eastern Europe, whereas Sardinia and north Europe countries except for Finland marked a plateau in the growth of T1DM incidence ${ }^{4}$.

During the 1996-2006 period, the incidence of childhood-onset T1DM among Montenegro children under 15 years of age was 13.4/100,000 per year. The annual increase rate for this period was $4.6 \%{ }^{5}$. 
Many registries describe seasonal variation in the date of T1DM diagnosis, with a note that the disease is most often diagnosed during winter months ${ }^{6}$. This is associated with the number of sunny days, which is important for the synthesis of vitamin $\mathrm{D}^{7}$ and for seasonal infections ${ }^{8}$.

The aim of this study was to examine changes in the age distribution at onset of T1DM in Montenegro children aged $<15$ years during a 15 -year period (1997-2011) and to analyze the seasonal pattern of the disease diagnosis.

\section{Material and Methods}

\section{Geographical and population data}

Montenegro is located in South-Eastern Europe, with an area of $13812 \mathrm{~km}^{2}$ and a population of 620,145 (according to the 2011 census), including 118,751 (19\%) children in the 0-14 age group 9

\section{Ascertainment}

Diabetes onset in children and adolescents aged $<15$ years was documented according to the EU-
RODIAB criteria ${ }^{1}$. All children living in Montenegro and diagnosed with T1DM from 1996 to 2011 were included in the study. They were admitted to the Institute for Sick Children, Podgorica, the only tertiary care children's hospital in Montenegro. The register of children suffering from T1DM exists since 1982, but prospective registration as part of the EURODIAB study started in 2007. Hospital case records served as primary source of ascertainment. The National Public Health Institute diabetes register and register of children receiving free test stripes in the pharmacy were used as independent secondary and tertiary sources of ascertainment. Completeness of ascertainment was estimated with the capturerecapture method ${ }^{10}$.

\section{Statistical analysis}

Children population was obtained from the 2003 and 2011 census data, as well as the mid-year population estimates for other years in the study, published by the Statistical Office of Montenegro (MONSTAT) ${ }^{9}$. Age and sex specific incidence rates were calculated from the number of new cases divided by the estimated number of person-years at risk in the respective age

Table 1. Age and sex specific incidence rates of type 1 diabetes mellitus in Montenegro during 1997-2012

\begin{tabular}{|l|c|c|c|c|c|c|}
\hline Sex & $\begin{array}{c}\text { Age } \\
\text { group } \\
\text { (yrs) }\end{array}$ & $1997-2001$ & $2002-2006$ & $2007-2011$ & $\begin{array}{c}\text { Average percentage } \\
\text { increase of incidence per } \\
5 \text {-yr periods } \\
\%(95 \% \text { CI })\end{array}$ & $p$ \\
\hline \multirow{6}{*}{ Boys } & $0-4$ & $6.9(1.2-15.0)$ & $8.6(-0.1-17.3)$ & $17.9(1.8-34.0)$ & $64.7(20.6-10.7)$ & 0.004 \\
& $5-9$ & $9.0(4.9-13.2)$ & $11.8(0.2-23.4)$ & $24.5(9.3-39.8)$ & $52.8(16.9-88.8)$ & 0.004 \\
& $10-14$ & $15.9(7.2-25.5)$ & $23.8(9.9-37.6)$ & $23.0(12.5-33.5)$ & $17.9(-10.0-45.8)$ & 0.209 \\
& $0-14^{*}$ & $10.4(5.5-15.3)$ & $14.3(7.2-21.5)$ & $21.5(14.4-28.5)$ & $35.3(15.9-54.7)$ & 0.000 \\
& $0-4$ & $9.3(5.2-13.4)$ & $11.3(3.0-19.6)$ & $9.8(4.2-15.5)$ & $3.1(-40.6-46.8)$ & 0.888 \\
Girls & $5-9$ & $11.6(3.9-19.3)$ & $25.2(11.7-35.6)$ & $23.5(7.8-39.1)$ & $31.1(0.0-62.3)$ & 0.050 \\
& $10-14$ & $12.0(2.8-21.3)$ & $17.2(12.8-21.6)$ & $14.8(7.4-22.1)$ & $10.0(-24.2-44.2)$ & 0.566 \\
& $0-14^{*}$ & $10.8(7.0-14.7)$ & $17.3(12.7-21.9)$ & $15.4(8.7-22.2)$ & $17.6(-2.7-37.9)$ & 0.089 \\
& $0-4$ & $8.1(4.9-11.2)$ & $9.9(3.1-16.6)$ & $14.0(3.7-24.4)$ & $28.2(-1.7-58.2)$ & 0.065 \\
All & $5-9$ & $10.3(6.3-14.2)$ & $18.3(14.3-22.2)$ & $24.0(13.1-34.9)$ & $40.6(17.2-64.1)$ & 0.001 \\
& $10-14$ & $14.0(6.9-21.1)$ & $20.6(15.0-26.2)$ & $19.0(12.4-25.6)$ & $14.9(-6.7-36.5)$ & 0.177 \\
& $0-14^{*}$ & $10.6(7.2-14.0)$ & $15.8(11.7-19.8)$ & $18.6(13.0-24.1)$ & $26.9(12.9-40.9)$ & 0.000 \\
\hline
\end{tabular}

Incidence per 100000 children per year in 5-year periods (95\% CI) and mean percentage increase per 5-year periods; ${ }^{*}$ age standardized incidence 
Table 2. Newly diagnosed cases of type 1 diabetes mellitus and annual incidence per 100000 population with 95 confidence interval (95\% CI)

\begin{tabular}{|c|c|c|c|c|c|c|c|}
\hline Year & No. of cases & $\begin{array}{c}\text { Annual } \\
\text { incidence } \\
\text { (boys and girls) }\end{array}$ & $95 \% \mathrm{CI}$ & $\begin{array}{c}\text { Annual } \\
\text { incidence } \\
\text { (boys) }\end{array}$ & $95 \%$ CI & $\begin{array}{c}\text { Annual } \\
\text { incidence } \\
\text { (girls) }\end{array}$ & 95\% CI \\
\hline 2007 & 28 & 21.8 & $13.7-30.0$ & 25.3 & $13.2-37.5$ & 18.0 & $7.29-28.82$ \\
\hline 2008 & 26 & 21.6 & $13.2-30.0$ & 29.0 & $15.5-42.6$ & 13.6 & $4.06-23.06$ \\
\hline 2009 & 14 & 10.8 & $5.1-16.5$ & 14.6 & $5.6-23.7$ & 6.8 & $0.07-13.56$ \\
\hline 2010 & 23 & 19.7 & $11.6-27.8$ & 18.8 & $7.6-30.0$ & 20.5 & $8.82-32.28$ \\
\hline 2011 & 23 & 18.8 & $11.1-26.6$ & 19.5 & $8.4-30.6$ & 18.1 & $7.36-28.83$ \\
\hline
\end{tabular}

group (0-14, 0-4, 5-9 and 10-14 years) for each sex. Confidence intervals were calculated assuming a Poisson distribution. Age and sex standardized incidence rates were obtained for the 0-14 age group using the direct method with the world standard population. Poisson regression models were also used to estimate the effects of sex, age (three age groups: 0-4, 5-9 and 10-14 years) and calendar time (three 5-year periods: 1997-2001, 2002-2006 and 2007-2011). Annual incidence rates were calculated from 1997 to 2011. The rates calculated from 1997 to 2006 were found to be identical to those previously published ${ }^{5}$. Statistical analyses were performed using SPSS 17 . The level of statistical significance was set at $\mathrm{p}<0.05$.

\section{Results}

Overall ascertainment using the three independent sources and capture-recapture method was estimated to be $100 \%$ complete for the study period. The incidence rates according to sex, age group and calendar period are shown in Table 1 . The incidence increased over the study period from $10.6 / 100,000$ (95\% CI: 7.214.0 ) in $1997-2001$ to $18.6 / 100,000$ (95\% CI: $13.0-$ $24.1)$ in 2007-2011. The mean percentage increase of incidence per 5-year period was $26.9 \%$. There was a plateau from 2007 to 2011, with no increase in the incidence in that period (Table 2).

Two youngest age groups (0-4 and 5-9 years) had the highest relative increase of incidence. We found a steep increase in the incidence of T1DM in Montenegro boys aged $<5$ years $(64.7 \%)$ per three 5 -year periods (Fig. 1). The mean annual incidence peaked during 2002-2006 at 25.2/100,000 (95\% CI: $11.7-$ $35.6)$ in 5- to 9-year-old girls and during 2007-2011 at 24.5/100,000 (95\% CI: 9.3-39.8) in 5- to 9-year-old boys (Table 1 ).
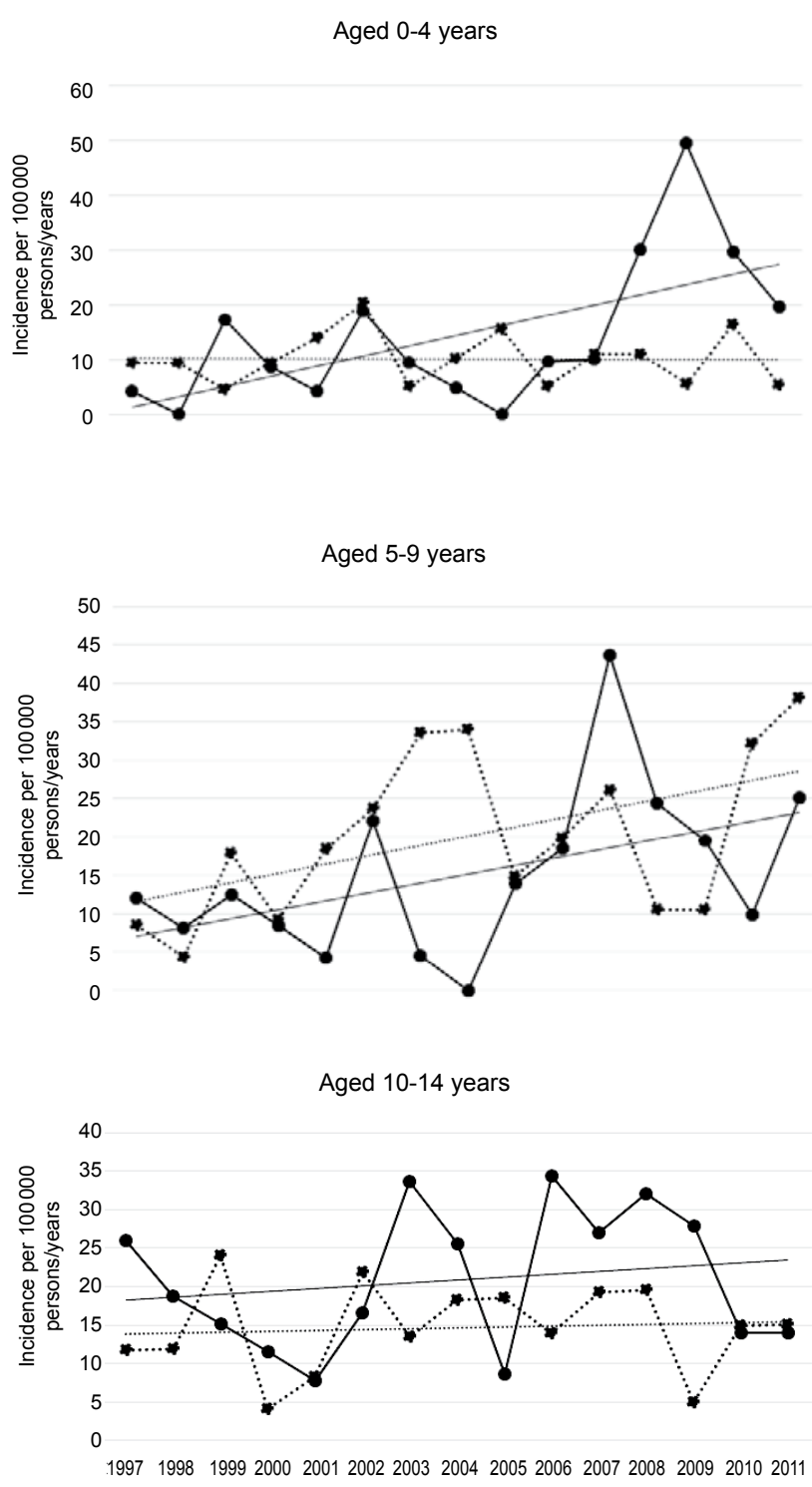

$\longrightarrow$ - Male ........ Female

Fig. 1. Time trends in age- and sex-specific incidence rates in the 1997-2012 period. 


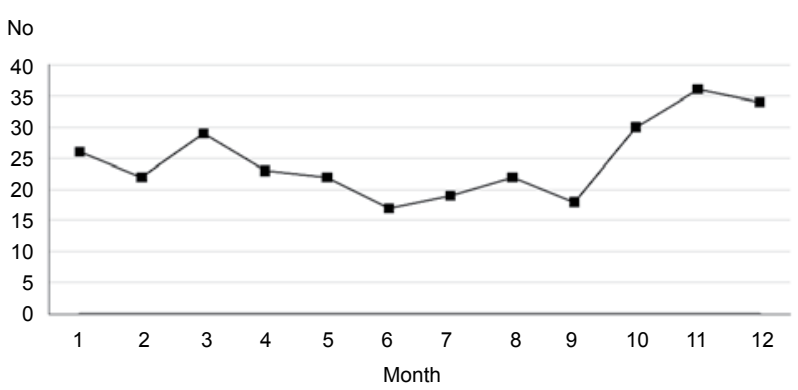

Fig. 2. Number of children aged 0-14 years diagnosed with type 1 diabetes each month.

The mean age at onset for the entire study period was $7.9 \pm 3.9$ years. The mean age at onset was $7.9 \pm 4.2$ years in 2007-2001, 8.1 \pm 3.8 years in 2002-2006, and $7.6 \pm 3.9$ years in $2007-2011$ period. The mean age at diagnosis decreased during the study period, but not statistically significantly $(\mathrm{p}=0.685)$.

The number of cases according to months for all children is presented graphically in Figure 2. The greatest number of cases were diagnosed from October to March, i.e. in autumn and winter months.

\section{Discussion}

This study represents an updated analysis of epidemiological data from the Montenegro Childhood Diabetes Registry confirming the increasing incidence of childhood-onset T1DM over the 15-year study period. Two youngest age groups (0-4 and 5-9 years) had the highest relative increase. This is in accordance with other studies reporting the increasing incidence of T1DM mostly in younger age group ${ }^{11-14}$, but is completely different from data reported in Croatia where the increase in the disease incidence ceased in the youngest children ${ }^{15}$. Similar to some other studies ${ }^{16,17}$, we found a steep increase in the incidence T1DM in Montenegro boys under five years of age. A slight predominance of male children is noted in the populations with a higher incidence of T1DM. This could mean that external factors affect male children more than female children and speed up the processes that lead to earlier clinical manifestation of diabetes ${ }^{18}$.

The incidence of T1DM increased in Montenegro from 1997 to 2007, with a plateau of about 21.8/100,000 since 2007, followed by stable rates until 2011 (Table 2). Previously, stabilization of rates was observed from 2003 to 2006. Similar results were obtained in some high risk countries, which reached a plateau in the disease incidence and shift toward younger age at disease onset $^{19,20}$. According to some authors, the increase of T1DM incidence is the consequence of earlier clinical presentation rather than of global increase of incidence, earlier exposure to external factors for the development of T1DM, and faster progression of the subclinical disease process to overt diabetes ${ }^{21}$. This points to the importance of those factors which are active in the prenatal and perinatal period, such as birth weight, maternal age, type of delivery, duration of breastfeeding, and virus infections, especially enteroviruses ${ }^{8,22}$. Data on early introduction of cow milk into diet as a risk factor for the onset of diabetes are controversial. Children with higher birth weight and born by an older mother are at a greater risk of having diabetes ${ }^{23,24}$. In the last decade, women in Montenegro are forming their families much later, which can slightly contribute to the increase of T1DM incidence?.

Hyppönen et al. found that children from Finland who developed T1DM were heavier and taller than control children ${ }^{25}$. According to the so called accelerator hypothesis, obesity and resistance to insulin stimulate the autoimmune process and earlier presentation of diabetes. In Sweden, there is a reversed diabetes incidence trend, starting in 2000, which is a result of preventive programs for suppression of obesity ${ }^{4}$.

The most recent publication by Martinovic et al. ${ }^{26}$ shows that in Montenegro significant changes occurred in people's diet and that there is more frequent occurrence of obesity among schoolchildren. According to the latest International Obesity Task Force (OITF) reference, there are $17.6 \%$ of overweight children and $5.3 \%$ of obese children. Obesity is two times more frequent among Montenegro boys compared with girls (7.0\% vs. 3.5\%).

Climate in Montenegro is continental, Mediterranean and mountain ${ }^{27}$. We investigated seasonal variation during the study period. The greatest number of cases were diagnosed during autumn and winter months. Seasonality in monthly case counts of T1DM is apparent in most EURODIAB centers, in all age groups and both sexes ${ }^{6}$.

In conclusion, the results of this study indicated that T1DM incidence was still increasing in younger age groups, especially in boys aged $0-4$ years. We need further research of the factors which have an impact 
on the increase of T1DM incidence. Epidemiological studies will contribute to better understanding of diabetes and better planning of health care for the children suffering from T1DM.

\section{References}

1. Soltesz G, Patterson CC, Dahlquist G; EURODIAB Study Group. Worldwide childhood type 1 diabetes incidence - what can we learn from epidemiology? Pediatr Diabetes. 2007;8 (6):6-14.

2. Patterson CC, Dahlquist GG, Gyürüs E, Green A, Soltész G; EURODIAB Study Group. Incidence trends for childhood type 1 diabetes in Europe during 1989-2003 and predicted new cases 2005-2020 - a multicentre prospective registration study. Lancet. 2009;373:2027-33. doi: 10.1016/S0140-6736(09)60568-7.

3. Patterson C, Gyürüs E, Rosenbauer J, Cinek O, Neu A, Schober E, Parslow RC, et al. Trends in childhood type 1 diabetes incidence in Europe during 1989-2008: evidence of non-uniformity over time in incidence rates. Diabetologia. 2012;55(8):2142-7. doi: 10.1007/s00125-012-2571-8.

4. Berhan Y, Waernbaum I, Lind T, Mollsten A, Dahlquist G; Swedish Childhood Diabetes Study Group. Thirty years of prospective nationwide incidence of childhood type 1 diabetes. The accelerating increase by time tends to level off in Sweden. Diabetes. 2011;60:577-81. doi: 10.2337/db10-0813.

5. Samardzic M, Marinkovic J, Kocev N, Curovic N, Terzic N. Increasing incidence of childhood type 1 diabetes in Montenegro from 1997 to 2006. Pediatr Diabetes. 2009:11:412-7. doi: 10.1111/j.1399-5448.2009.00617.x.

6. Patterson C, Gyürüs E, Rosenbauer J, Cinek O, Neu A, Dahlquist $\mathrm{G}$, et al. Seasonal variation in month of diagnosis in children with type 1 diabetes registered in 23 European centers during 1989-2008: little short-term influence of sunshine hours or average temperature. Pediatr Diabetes. 2015;16(8):573-80. doi: 10.1111/pedi.12227.

7. Cooper JD, Smyth DJ, Walker NM, Stevens H, Burren OS, Wallace $\mathrm{C}$, et al. Inherited variation in vitamin $\mathrm{D}$ genes is associated with predisposition to autoimmune type 1 diabetes. Diabetes 2011;60:1624-31. doi: 10.2337/db10-1656.

8. Krogvold L, Edwin B, Buanes T, Frisk G, Skog O, Anagandula M, et al. Detection of a low-grade enteroviral infection in the islets of Langerhans of living patients newly diagnosed with type 1 diabetes. Diabetes. 2015;64(5):1682-7. doi: 10.2337/db14-1370.

9. Statistical Yearbook of Montenegro 2011. Population by age group and sex, according to 2011 census. Available from http://www.monstat.org/eng/

10. Knowles RL, Smith A, Lynn R, Rahi JS. Using multiple sources to improve and measure case ascertainment in surveillance studies: 20 years of the British Paediatric Surveillance Unit. J Public Health (Oxf). 2006;28:157-65.
11. Karvonen M, Pitkäniemi J, Tuomilehto J. The onset age of type 1 diabetes in Finnish children has become younger. The Finnish Childhood Diabetes Registry Group. Diabetes Care. 1999;22(7):1066-70.

12. Gyurus EK, Patterson C, Soltesz G; Hungarian Childhood Diabetes Epidemiology Group. Twenty-one years of prospective incidence of childhood type 1 diabetes in Hungary - the rising trend continues (or peaks and highlands?). Pediatr Diabetes. 2012;13(1):21-5. doi: 10.1111/j.1399-5448 .2011.00826.x.

13. Ehehalt S, Dietz K, Willasch AM, Neu A. Baden-Württemberg Diabetes Incidence Registry (DIARY) Group. Epidemiological perspectives on type 1 diabetes in childhood and adolescence in Germany: 20 years of the Baden-Württemberg Diabetes Incidence Registry (DIARY). Diabetes Care. 2010;33(2):338-40. doi: 10.2337/dc09-1503.

14. Skordis N, Efstathiou E, Kyriakides TC, Savvidou A, Savva SC, Phylactou LA, et al. Epidemiology of type 1 diabetes mellitus in Cyprus: rising incidence at the dawn of the $21^{\text {st }}$ century. Hormones (Athens). 2012;1(1):86-93.

15. Rojnic Putarek N, Ille J, Spehar Uroic A, Skrabic V, Stipancic $\mathrm{G}, \mathrm{Krnic} \mathrm{N}$, et al. Incidence of type 1 diabetes mellitus in 0to $14-y r-o l d ~ c h i l d r e n$ in Croatia - 2004 to 2012 study. Pediatr Diabetes. 2015;16(6):448-53. doi: 10.1111/pedi.12197.

16. Weets I, Rooman R, Coeckelberghs M, De Block C, Van Gaal L, Kaufman JM, et al. The age at diagnosis of type 1 diabetes continues to decrease in Belgian boys but not in girls: a 15-year survey. Diabetes Metab Res Rev. 2007;23:637-43.

17. Newhook LA, Penney S, Fiander J, Dowden J. Recent incidence of type 1 diabetes mellitus in children 0-14 years in Newfoundland and Labrador, Canada climbs to over 45/100,000: a retrospective time trend study. BMC Res Notes. 2012;5:628. doi: 10.1186/1756-0500-5-628.

18. Charkaluk ML, Czernichow P, Lévy-Marchal C. Incidence data of childhood-onset type I diabetes in France during 1988-1997: the case for a shift toward younger age at onset. Pediatr Res. 2002;52(6):859-62.

19. Harjutsalo V, Sund R, Knip M, Groop PH. Incidence of type 1 diabetes in Finland. JAMA. 2013;310(4):427-8. doi: 10.1001/jama.2013.8399.

20. Skrivarhaug T, Stene LC, Drivvoll AK, Strøm H, Joner G; Norwegian Childhood Diabetes Study Group. Incidence of type 1 diabetes in Norway among children aged 0-14 years between 1989 and 2012: has the incidence stopped rising? Results from the Norwegian Childhood Diabetes Registry. Diabetologia. 2014;57(1):57-62. doi: 10.1007/s00125-0133090-y.

21. Dahlquist GG, Nyström L, Patterson CC; Swedish Childhood Diabetes Study Group; Diabetes Incidence in Sweden Study Group. Incidence of type 1 diabetes in Sweden among individuals aged 0-34 years, 1983-2007: an analysis of time trends. Diabetes Care. 2011;34 (8):1754-9. doi: 10.2337/ dc11-0056. 
22. Borras V, Freitas A, Castell C, Gispert R, Jané M. Type 1 diabetes and perinatal factors in Catalonia (Spain). Pediatr Diabetes. 2011;12(4 Pt 2):419-23. doi: 10.1111/j.1399-5448 .2010.00711.x.

23. Cardwell CR, Stene LC, Joner G, Davis EA, Cinek O, Patterson CC, et al. Birthweight and the risk of childhood-onset type 1 diabetes: a meta-analysis of observational studies using individual patient data. Diabetologia. 2010;53(4):641-51. doi: 10.1007/s00125-009-1648-5.

24. Cardwell CR, Stene LC, Joner G, Bulsara MK, Cinek O, Patterson CC, et al. Maternal age at birth and childhood type 1 diabetes: a pooled analysis of 30 observational studies. Diabetes. 2010;59(2):486-94. doi: 10.2337/db09-1166.
25. Hyppönen E, Virtanen SM, Kenward MG, Knip M, Akerblom HK; Childhood Diabetes in Finland Study Group. Obesity, increased linear growth, and risk of type 1 diabetes in children. Diabetes Care. 2000;23(12):1755-60.

26. Martinovic M, Belojevic G, Evans GW, Lausevic D, Asanin B, Samardzic M, et al: Prevalence of and contributing factors for overweight and obesity among Montenegrin schoolchildren. Eur J Public Health. 2015;25(5):833-9. doi: 10.1093/ eurpub/ckv071.

27. Hydrometeorological Service of Montenegro. Available from: www.meteo.co.me.

Sažetak

\section{NOVI PODACI O INCIDENCIJI DIJABETESA TIPA 1 U CRNOJ GORI: BOLEST POČINJE U MLAĐOJ ŽIVOTNOJ DOBI}

\section{Samardžić, M. Martinović, M. Nedović-Vuković i M. Popović-Samardžić}

Posljednjih desetljeća velik broj istraživanja ukazuje na dramatičan porast incidencije dijabetesa tipa $1 \mathrm{u}$ cijelom svijetu, naročito u mlađim dobnim skupinama. Cilj ovoga istraživanja bio je obnoviti podatke iz prethodne studije, istražiti promjene u dobi pojavljivanja dijabetesa kod djece u dobi od 0 do 14 godina (1997.-2011.) i analizirati sezonski obrazac pojave bolesti. Kao prvi izvor poslužili su podaci iz registra oboljelih od šećerne bolesti, a kao drugi i treći izvor korištena su bolnička otpusna pisma i registar djece koja primaju besplatno test trake u ljekarnama. Za izračun standardizirane incidencije korišten je Poissonov regresijski model. Upotrebom metode capture-recapture pouzdanost podataka procijenjena je na 100\%. Standardizirana incidencija za dobnu skupinu 0-14 godina bila je 18,6/100.000 (95\% CI: 13,0-24,1) od 2007. do 2011. godine u usporedbi s incidencijom od 13,4/100.000 95\% CI, 11,5-15,5) od 1997. do 2006. godine. Incidencija dijabetesa tipa 1 rasla je pretežito u mlađim dobnim skupinama. Relativno povećanje incidencije u petogodišnjem razdoblju bilo je najveće kod dječaka dobnih skupina 0-4 i 5-9 godina: 64,7\% (95\% CI: 20,6-10,7; p=0,004) odnosno 52,8\% (95\% CI: 16,9-88,8; p=0,004). Izražen je sezonski obrazac, tj. bolest se najčešće dijagnosticira u jesenjim i zimskim mjesecima. U zaključku, dijabetes tipa 1 u Crnoj Gori dijagnosticira se kod djece sve mlađe dobi. Naši rezultati ukazuju na sezonski obrazac pojave bolesti.

Ključne riječi: Dijabetes melitus, tip 1; Dijete; Incidencija; Epidemiologija; Crna Gora 